\title{
ANALISIS PUTUSAN BEBAS TERHADAP TERPIDANA KASUS PEMBUNUHAN SADIS DAN BERENCANA (STUDI PUTUSAN NOMOR : 35/PID.B/2012/PN.BTM)
}

\author{
Yosua Kelvin dan Parningotan Malau
}

\author{
Program Studi Ilmu Hukum, Fakultas Ilmu Sosial dan Humaniora, Universitas Putera \\ Batam, Indonesia \\ Jalan Raden Patah, Nagoya, Batam. Kode Pos 29444 \\ doktormalau2019@gmail.com
}

\begin{abstract}
The purpose of this study is to analyze the perspective of the Indonesian criminal law against life imprisonment or capital punishment in criminal cases of planned murder and analyze the judges' considerations of a free verdict (vrijspraak) of a criminal case with a decision number: 35 / Pid.B / 2012 / Pn. Btm in accordance with the expectations of law and justice. The author is of the view that the verdict is very unfair, where the Terdakwat Mindo who is the main perpetrator is acquitted by the panel of judges, while the Terdakwats Gugun and Terdakwat Ros who act as assistants and participate have been convicted by the panel of judges in committing the planned murder. The panel of judges also did not consider the interests of the victims, apart from that the verdict did not rely on the urgency of cases of humanitarian crimes in Indonesia that were carried out cruelly and sadistically to the victims, so that it would have an impact on the damage and disruption of the order of the social order that lives and develops in society. . Supreme Court decision with decision number: $1691 \mathrm{~K} / \mathrm{Pid} /$ 2012 invalidate the wrong decision from the judex facti decision of Batam District Court number: 35 / Pid.B / 2012 / Pn.Btm, where in the ruling the Terdakwat was found guilty in carrying out planned murder together and sentence the Terdakwat to life imprisonment.
\end{abstract}

Keywords: Verdict, Free, Police

\begin{abstract}
Abstrak Tujuan penelitian ini menganalisis perspektif hukum pidana Indonesia terhadap pidana seumur hidup atau pidana mati dalam kasus tindak pidana pembunuhan berencana dan menganalisis pertimbangan hakim atas putusan bebas (vrijspraak) kasus tindak pidana pembunuhan berencana dengan nomor putusan : 35/Pid.B/2012/Pn.Btm sesuai dengan harapan hukum dan keadilan. Penulis berpandangan bahwa putusan tersebut sangat tidak adil, dimana terdakwa Mindo yang merupakan pelaku utama diputus bebas oleh majelis hakim, sedangkan terdakwa Gugun dan terdakwa Ros yang berperan sebagai pembantu dan turut serta sudah diputus bersalah oleh majelis hakim dalam melakukan pembunuhan berencana tersebut. Majelis hakim juga tidak mempertimbangkan kepentingan korban, selain itu putusannya tidak sama sekali bertumpu terhadap urgensinya kasus-kasus kejahatan kemanusiaan di Indonesia yang dilakukan dengan keji dan sadis kepada korban, sehingga akan berdampak pada kerusakan dan terganggunya tatanan ketertiban sosial yang hidup dan berkembang di dalam masyarakat. Putusan MA dengan nomor putusan : $1691 \mathrm{~K} / \mathrm{Pid} / 2012$ membatalkan putusan yang keliru dari putusan judex facti pengadilan negeri Batam nomor : 35/Pid.B/2012/Pn.Btm tersebut, dimana dalam amar putusannya terdakwa dinyatakan terbukti bersalah dalam melakukan pembunuhan berencana secara bersama-sama serta menghukum terdakwa dengan pidana penjara selama seumur hidup.
\end{abstract}

Kata Kunci: Putusan , Bebas, Kepolisian 


\section{Pendahuluan}

Pancasila sebagai falsafah bangsa Indonesia, menjadi sebuah landasan ataupun sumber hukum Indonesia. Sistem hukum Indonesia yang mana berujung pada cita hukum (rechtsidee, ius constituendum) yang berakar dalam Pancasila. Pancasila sebagai pandangan hidup (falsafah) bangsa Indonesia secara formal tercantum dalam Pembukaan Undang-Undang Dasar Negara Republik Indonesia (selanjutnya disingkat sebagai UUD NRI) Tahun 1945, yaitu dalam 5 (lima) dasar kefilsafatan bernegara yang kemudian diuraikan dalam pasal-pasal batang tubuh UUD NRI Tahun 1945 (Kaelan, 2013, hal 45). Pancasila dan Pembukaan UUD NRI Tahun 1945 sebagai norma dasar (grundnorm, staatsfundamentalnorm) sebagai sumber hukum positif (Sahid Raharjo, makalah, Cita Negara, Hukum Pancasila). Pembukaan UUD NRI Tahun 1945 dipertahankan ke dalam peraturan perundang-undangan dibentuk membangun dan menjalankan roda berbangsa dan bernegara ${ }^{1}$. Hukum mengatur pergaulan hidup (social control) dan secara tegas bersifat memaksa, sehingga disaat seseorang melakukan pelanggaran terhadap aturan hukum atas kesalahannya (schuld) dapat dikenakan hukuman (punishment), termasuk penjatuhan sanksi pidana. Sistem Peradilan Pidana (criminal justice system) adalah sebuah sistem yang dijalankan negara guna mengatur fungsi, kedudukan, dan wewenang lembaga penegak hukum pidana (de jurist als medespeler $)^{2}$.

Setiap manusia dalam menjalankan kehidupan pastinya saling membutuhkan satu dengan lainnya dan berdasarkan sifat dan keinginan yang berbeda. Manfaat hukum (legal function) adalah memberikan pengaturan dan keseimbangan terhadap sifat dan keinginan bagi setiap orang yang berbeda-beda ini agar setiap hubungan masyarakat dapat berjalan dengan baik dan dalam kedamaian ${ }^{3}$. Hukum pidana (criminal law, strafrecht, penal law) materiil, pengaturannya (regeling) terdapat dalam Kitab Undang-Undang Hukum Pidana (selanjutnya disebut sebagai KUHP) dan maupun diluar KUHP. KUHP (wetboek van strafrecht voor nederlands-indie, criminal code) sekumpulan aturan-aturan tertulis (statute law, written law) yang berisi norma-norma dan larangan yang mana jika dilakukan dapat menimbulkan kerugian bagi setiap orang dan barang siapa yang melakukan pelanggaran terhadap aturan (rules) tersebut dapat dipidana menurut perbuatannya (deed) dan kesalahannya. Undang-undang jenayah adalah pengaturan hukum yang terdapat di negara yang berdaulat (de facto dan de jure) yang berisi tindakan yang dilarang, serta ancaman jenayah terhadap orang yang melakukan pelanggaran atau tidak mematuhi peraturan undang-undang. Tujuan umum hukum pidana (general purpose), iaitu menjaga ketenteraman awam, sementara objektif tertentu (special purpose) iaitu untuk mengatasi jenayah dan mencegah jenayah (penal policy) ${ }^{4}$.

\footnotetext{
${ }^{1}$ Prasetyo, T. (2014). Membangun Sistem Hukum Pancasila Yang Merdeka Dari Korupsi dan Menjunjung Ham. Jurnal Refleksi Hukum, 8(1), 19-26.

${ }^{2}$ Ibid.

3 Simamora, J. (2014a). Kepastian Hukum Pengajuan Kasasi Oleh Jaksa Penuntut Umum Terhadap Vonis Bebas Kajian Putusan Mahkamah Konstitusi Nomor 114/Puu-X/2012. Jurnal Yudisial, 7(1), 1-17.

${ }^{4}$ Marbun, R. (2014). Grand Design Politik Hukum Pidana dan Sistem Hukum Pidana Indonesia Berdasarkan Pancasila dan Undang-Undang Dasar Negara Republik Indonesia 1945. Padjadjaran Journal of Law, 1(3), 558-577.
} 
Perkembangan sanksi pidana saat ini sering dijumpai dalam setiap undang-undang (act, law) yang mengakibatkan pergeseran politik dalam jenayah (kebijakan berkanun) mengenai pelaksanaan undang-undang jenayah yang pada awalnya merupakan jalan terakhir (pemulihan maksimum) kepada godaan pertama (primum remedium). Hukum pidana bersifat primum remedium dan tidak ada alternatif lain yang dapat digunakan, sebaliknya dengan ultimum remedium sering tidak menimbulkan efek jera sehingga tersangka/terdakwa mengulangi perbuatannya (recidivist). Kerugian yang umumnya sulit dipulihkan (irreparable), sering diperhadapkan dengan penjatuhan hukum yang ringan dan tidak lagi dipandang sebagai hukuman pelaku ${ }^{5}$ Kejahatan menghilangkan nyawa seseorang contoh delik yang mengharuskan hukum pidana sebagai sarana utama, dasar atau fondasi penegakan hukum ${ }^{6}$

Tindak pidana (strafbaarfeit, delicium, delict) pembunuhan sangat bertentangan UUD NRI Tahun 1945, sebagaimana Pasal 28A "setiap orang mempunyai hak untuk hidup dan berhak untuk mempertahankan hidup dan nyawanya". Kehidupan merupakan karunia yang setiap orang dapatkan dari Tuhan Yang Maha Kuasa, oleh itu negara mesti menjamin agar setiap orang dapat hidup dan dapat mempertahankan hidupnya. Didalam KUHP juga mendapatkan pengaturan terhadap ketentuan pidana terhadap perbuatan kejahatan yang menghilangkan nyawa seseorang maupun banyak orang dengan sengaja maupun tidak sengaja dalam Buku Ke II Bab-XIX KUHP yang terdapat 13 Pasal, yakni dari Pasal 338 sampai Pasal 350. Pembunuhan dengan perencanaan (mord, voorbedachte rade) menjadi alasan pemberatan sebagaimana pasal 340 KUHP. Sebelum melakukan perbuatan, pelaku mempunyai waktu yang luang untuk memikirkan dengan tenang caranya untuk membunuh serta usaha-usaha apa saja agar perbuatannya selesai tanpa siapapun mengetahuinya. Pelaku sama sekali tidak lagi mempunyai rasa iba serta menghargai, dan nilai-nilai Ketuhanan. Nilai kemanusiaan tidak lagi dihargai/dihormati oleh pelaku? .

Sebagai negara hukum, negara melalui badan peradilan harus lebih mendalami masalah-masalah kejahatan (criminal cases) terutama kejahatan menghilangkan nyawa seseorang dilakukan dengan sadis, diluar batas kemanusiaan ${ }^{8}$ Tindak pidana pembunuhan (murder, misdrijven tegen het leven) di dalam pasal 338 KUHP adalah menghilangkan nyawa seseorang, dimana pelaku/tersangka/terdakwa merampas hak hidup seseorang yang tidak boleh diganti dengan apa-apa ${ }^{9}$. Tindak pidana pembunuhan yang disertai dengan kejahatan, sebagaimana diatur dalam pasal 339 KUHP yaitu pembunuhan yang

\footnotetext{
${ }^{5}$ Anindyajati, T., Rachman, I. N., \& Onita, A. A. D. (2015). Konstitusionalitas Norma Sanksi Pidana sebagai Ultimum Remedium dalam Pembentukan Perundang-undangan. Jurnal Konstitusi, 12(872-893).

6 Rahmawati, N. A. (2013). Hukum Pidana Indonesia: Ultimum Remedium Atau Primum Remedium. Recidive (Jurnal Hukum Pidana Dan Penanggulangan Kejahatan), 2(1), 39-44.

7 Tresyani, E., D.A., K. N., \& Kusworoningtyas, Y. (2014). Pelaksanaan Pembuktian Tindak Pidana Pembunuhan Berencana Di Persidangan Oleh Penuntut Umum Kejaksaan Negeri Surakarta. Verstek Jurnal Hukum Acara, 2(2), 155-166.

${ }^{8}$ Simbolon, V. E. B., Simarmata, M., \& Rahmayanti. (2019). Tinjauan Yuridis terhadap Tindak Pidana Pembunuhan Berencana Menggunakan Besi Padat di Medan Tinjauan Kasus Nomor 2305/Pid.B/2017/Pn.Mdn. Jurnal Mercatoria, 12(1), 54-67.

9 Lumbantoruan, R. (2019). Analisis Yuridis Putusan Bebas terhadap Kasus Tindak Pidana Pembunuhan. Journal of Education, Humaniora and Social Sciences (JEHSS), 2(2), 399-411.
} 
didahului oleh suatu perbuatan pidana untuk mempersiapkan pelaksanaannya ${ }^{10}$. Perbuatan kejahatan yang disertai atau didahului oleh terdakwa merupakan delik yang berdiri sendiri dan merupakan pemberatan dari perbuatan tersebut. Tindak pidana pembunuhan berencana di dalam Pasal 340 KUHP yang berbunyi :

Barang siapa yang dengan sengaja dan dengan rancangan sebelumnya merampas nyawa orang lain, diancam dengan pembunuhan melalui rancangan, dengan hukuman mati atau penjara seumur hidup atau untuk jangka waktu yang ditentukan, maksimum dua puluh tahun.

Pengadilan negeri kota Medan yang pernah memeriksa seorang terdakwa (Terdakwat) yang melakukan tindak pidana pembunuhan berencana (nomor perkara : 2305/Pid.B/2017/PN.Mdn). Perbuatan terdakwa dalam merampas 6 (enam) nyawa korban dan membuat 1 (satu) korban luka berat menjadi pertimbangan majelis hakim dalam mengadili terdakwa dengan pidana mati (death penalty) (Simbolon et al., 2019). Pengadilan negeri kota Batam juga pernah mengadili seorang terdakwa yang melakukan Pembunuhan berencana dengan sadis sehingga terdakwa divonis pidana penjara selama seumur hidup (life sentence) pada putusan pengadilan negeri Batam (nomor perkara : 305/Pid.B/2019/PN Btm) dan pada tingkat banding, pengadilan tinggi Pekanbaru menguatkan vonis pidana seumur hidup tersebut (in kracht van gewijsde) (nomor perkara : 319/Pid.B/2019/PT PBR).

Penerapan pidana mati dipertahankan di dalam Rancangan Undang-Undang (RUU) KUHP Tahun 2019, terlihat pada Pasal 98 RUU KUHP berbunyi :

Hukuman mati secara alternatif diancam sebagai jalan terakhir untuk mencegah tindakan jenayah dan melindungi orang ramai ${ }^{11}$.

Mahkamah Agung melalui yurisprudensi (iurisprudentia, rechtsgeleerheid) mempertahankan pidana mati dan seumur hidup terhadap tindak pidana pembunuhan yang direncanakan, seperti keputusan kasasi Mahkamah Agung (judex juris) nomor : 773 K/PID/2015 dan nomor : 830 K/PID/2015. Oemar Seno Adji juga sependapat bahwa :

Selagi negara kita masih bertekad, masih bergelut dengan kehidupannya sendiri yang terancam, selagi perintah itu terganggu dan diancam oleh unsur-unsur yang tidak mengenal kemanusiaan, mereka masih memerlukan hukuman mati ${ }^{12}$

Bagir Manan sebagai pakar Hukum Tata Negara (HTN) dan mantan Ketua MA juga memandang hukuman mati untuk beberapa kasus pidana berat atau kejahatan luar biasa (extraordinary crime) masih sangat diperlukan, namun karena itu pidana maksimum

\footnotetext{
${ }^{10}$ Bip, T. R. (2017). KUHP Kitab Undang-Undang Hukum Pidana \& KUHAP Kitab UndangUndang Hukum Acara Pidana. Penerbit Bhuana Ilmu Populer.

${ }^{11}$ Widayati, L. S. (2017). Pidana Mati Dalam RUU KUHP: Perlukah Diatur Sebagai Pidana Yang Bersifat Khusus?(Death Penalty In The Bill Of Criminal Code: Should Regulated As A Special Punishment?). Negara Hukum: Membangun Hukum Untuk Keadilan Dan Kesejahteraan, 7(2), 167-194.

${ }^{12}$ Runtunuwu, G. M. (2013). Penjatuhan Pidana Mati Bagi Pelaku Tindak Pidana Narkotika. Lex Crimen, 2(6), 49-57.
} 
dan mutlak, hakim, jaksa, polisi harus dengan keyakinan dan bukti yang sangat kuat ${ }^{13}$. Putusan Mahkamah Konstitusi nomor 2-3/PUU-V/2007 tanggal 30 Oktober 2007 menegaskan bahwa hukum positif Indonesia masih menganut dan membenarkan penerapan sanksi pidana hukuman mati ${ }^{14}$. Sanksi pidana penjara seumur hidup kerap sebagai opsi pilihan dari hukuman mati, kerana penjara seumur hidup berkaitan dengan fungsi subsidair yang penerapan bersifat alternatif ${ }^{15}$

Tujuan pemidanaan menurut teori adalah memiliki 3 (tiga) teori yaitu teori pembalasan menjelaskan sistem pemidanaan adalah suatu bentuk pembalasan dari tindakan jahat (actus reus) yang diperbuat oleh pelaku (quia peccatum est) ${ }^{16}$ Teori kedua adalah teori tujuan, teori ini diklasifikasikan menjadi 2 (dua) yaitu pencegahan umum dan pencegahan khas. Menurut E. Utrech pencegahan secara umum (prevensi general) bertujuan mencegah masyarakat melakukan perbuatan pidana, sedangkan pencegahan secara khusus (prevensi special) bertujuan mencegah pelaku mengulangi perbuatan pidana Teori ketiga yaitu teori gabungan yang berdasarkan gagasan tuntutan pembalasan pidana dan mempertahankan ketertiban masyarakat ${ }^{17}$.

Perkara pembunuhan berencana yang mendapatkan perhatian masyarakat kota Batam pada tahun 2011 yaitu perkara atas nama Mindo Tampubolon, dimana terdakwa melakukannya secara sadis dan keji bersama dengan Rosita Als Ros, dan Gugun Als Ujang terhadap korban Putri Mega Umboh. Kemudian majelis hakim pengadilan negeri Batam memeriksa, memutus dan mengadili perkara tersebut dengan nomor putusan No:35/Pid.B/2012/PN.Btm dan menyatakan bahwa defen dan tidak terbukti secara sah serta meyakinkan bahawa dia melakukan perbuatan jenayah seperti yang didakwa Jaksa Penuntut Umum dalam tindak pidana pembunuhan berencana tersebut sehingga membebaskan terdakwa Mindo Tampubolon dari segala dakwaan (vrijspraak).

Putusan tersebut sangat bertentangan dengan fakta-fakta hukum di persidangan dan pembuktian selama persidangan berlangsung. Majelis hakim di dalam pertimbangannya mengesampingkan bukti-bukti yang diajukan oleh penuntut umum, dengan demikian cara hakim dalam menerapkan hukum pembuktian telah salah dan keliru sehingga memutuskan perkara ini keliru. Apalagi putusan tersebut sangat bertolak belakang dengan putusan nomor : $1691 \mathrm{~K} / \mathrm{Pid} / 2012$, yang menyatakan terdakwa terbukti bersalah sehingga majelis Mahkamah Agung dalam amar putusannya menjatuhkan hukuman penjara seumur hidup kepada Terdakwa.

Berdasarkan apa yang telah dijelaskan di atas, maka dirasa perlu untuk meneliti secara lebih mendalam perspektif Undang-Undang mengenai hukuman seumur hidup atau

\footnotetext{
13 Julikawati, P. E. (2015). Bagir Manan: Hukuman Mati Perlu untuk Beberapa Pidana Berat. Tempo.Co.

${ }^{14}$ Anjari, W. (2015). Penjatuhan Pidana Mati di Indonesia dalam Perspektif Hak Asasi Manusia. Jurnal Widya Yustisia, 1(2), 107-115.

${ }^{15}$ Kamea, H. C. (2013). Pidana Penjara Seumur Hidup Dalam Sistem Hukum Pidana Di Indonesia. Lex Crimen, 2(2), 43-55.

${ }^{16}$ Anjari, W. (2015). Penjatuhan Pidana Mati di Indonesia dalam Perspektif Hak Asasi Manusia. Jurnal Widya Yustisia, 1(2), 107-115

${ }^{17}$ Husain, F. U. (2014). Implementasi Hukuman Seumur Hidup Dalam Praktik Di Indonesia Menurut KUHP. Lex Et Societatis, 1, 133-141.
} 
hukuman mati, yang mana dalam kasus tindak pidana pembunuhan berencana perkara atas nama Mindo Tampubolon dalam putusannya nomor: 35/Pid.B/2012/Pn.Btm menjatuhkan pidana bebas kepada terpidana.

\section{Metode Penelitian}

Kaedah penelitian yang digunakan yaitu penelitian hukum normatif. Pengumpulan data diperoleh dari kajian literatur dan keputusan mahkamah. Peneliti menggunakan metode penelitian normatif dengan pendekatan Undang-Undang (Statuta Approach) dan pendekatan kasus (Case Approach). Metode dan alat alat pengumpulan data yang digunakan dalam kajian ini adalah kajian dokumen seperti Undang-Undang dengan menilai bahan perpustakaan, termasuk bahan hukum primer dan bahan hukum sekunder. Langkah-langkah yang diambil untuk mengkaji dokumen yang berkaitan bermula dengan kajian dokumen mengenai bahan Undang-Undang primer dan bahan Undang-Undang sekunder. Kaedah analisis yang peneliti gunakan adalah dengan melakukan analisis kualitatif.

\section{Hasil Penelitian dan Pembahasan}

\section{A. Pertimbangan Hakim Atas Putusan Bebas (Vrijspraak) Kasus Tindak Pidana Pembunuhan Berencana Dengan Nomor Putusan : 35/Pid.B/2012/Pn.}

Literatur hukum banyak membahas tentang teori-teori keadilan, substansi hukum ditafsirkan oleh masing-masing penegak hukum dengan kepercayaan etika tentang adil dan tidak adil. Undang-Undang diciptakan berdasarkan nilai-nilai moral atau normanorma yang adil, sudah ada dan yang telah hidup serta berkembang dalam masyarakat. Hakim menjadi salah satu akses dalam mencari keadilan, keadilan yang dituangkan ke dalam pertimbangan putusan-putusannya tersebut. Hakim harus jeli dalam menilai suatu permasalahan hukum, dan jika hukum tersebut dirasa tidak cocok dengan keadaan saat ini, maka hakim wajib menelusuri serta menemukan nilai-nilai keadilan yang hidup dan berkembang dalam masyarakat sebagaimana adanya Pasal 5 ayat (1) UU Nomor 48 Tahun 2009 Tentang Kekuasaan Kehakiman, sehingga tujuan hukum dapat tercapai dan keadilan tidak hanya menjadi menjadi sebuah angan-angan di dalam suatu teks UndangUndang $^{18}$.

Negara Indonesia mengagaskan konsep keadilan dalam sila sila Pancasila, terutama dalam sila ke-3 (tiga) Pancasila yaitu "Keadilan sosial untuk semua orang Indonesia" sebagai sila dominan dan ditegaskan pada Pembukaan UUD NRI Tahun 1945 "dan dengan mewujudkan keadilan sosial untuk semua orang Indonesia"19. Hukum dengan tujuan sebenarnya adalah untuk mencari nilai-nilai keadilan dan bermuara pada keadilan

\footnotetext{
${ }^{18}$ Dwisvimiar, I. (2011). Keadilan dalam perspektif filsafat ilmu hukum. Jurnal Dinamika Hukum, 11(3), 522-531.

19 Susilo, A. B. (2011). Penegakan Hukum yang Berkeadilan dalam Perspektif Filsafat Hermeneutika Hukum: Suatu Alternatif Solusi terhadap Problematika Penegakan Hukum di Indonesia. Perspektif, 16(4), 214-226.
} 
yang hidup di masyarakat, karena esensi dari penegakan hukum adalah untuk mendapatkan keadilan ${ }^{20}$.

Namun demikian dalam proses peradilan pidana setiap masing-masing tersangka maupun terdakwa harus diterapkan sama tanpa membeda-beda kan satu sama lain, jadi terdakwa dapat menerima apa yang harus diterima dari perbuatannya menurut hukum dan korban mendapatkan apa yang menjadi tuntutan nya secara adil. Hakim dituntut untuk arif dan bijaksana dalam melihat setiap permasalahan-permasalahan hukum yang ada, sebagai penegak hukum yang adil sesuai Pasal 24 Ayat (1) UUD NRI Tahun 1945, bahkan dalam menjatuhkan sebuah putusan jangan sampai memihak atau berat sebelah dari salah satu kepentingan yaitu korban ataupun terdakwa, namun putusannya tersebut harus bercorong pada kesopanan, keadilan, kepentingan awam, dan ketenteraman awam. Hakim juga dituntut untuk mengali dan mengikuti nilai-nilai hukum yang hidup dan berkembang di dalam masyarakat sebagaimana Pasal 5 ayat (1) UU Nomor 48 Tahun 2009 Tentang Kekuasaan Kehakiman, hal tersebut diwajibkan kepada hakim dalam menjalankan tugas-tugasnya memecahkan dan menyelesaikan suatu permasalahan hukum yang ditemukan.

Sejalan dengan pendapat Rawls ${ }^{21}$ Kebajikan utama umat manusia adalah kebenaran dan keadilan yang tidak dapat dipertikaikan, sifat dan tujuan masyarakat yang adil merupakan bagian fundamental dari teori keadilan. Hukum dan institusi, walaupun efisien dan rapi, jika tidak adil harus direformasi atau dihapuskan. Subjek utama prinsip keadilan adalah struktur asas masyarakat dan susunan institusi sosial utama di dalamnya masyarakat yang saling bekerja sama. Tatanan-tatanan hukum dan lembaga yang netral dan konsisten, apa pun prinsip substantifnya dapat disebut sebagai keadilan formal, keadilan formal patuh pada prinsip atau ibarat orang patuh pada sistem ${ }^{22}$.

Pada dasarnya dalam pertimbangan majelis hakim atas putusan bebas (vrijspraak) kasus tindak pidana pembunuhan berencana dengan nomor putusan : 35/Pid.B/2012/PN.Btm, peneliti menemukan bahwa majelis hakim dalam pertimbangan putusannya telah mengabaikan teori keadilan. Sebagaimana majelis hakim tidak menerapkan ketentuan yang diatur dalam Pasal 197 ayat (1) huruf d KUHAP "pertimbangan yang disusun secara ringkas mengenai fakta dan keadaan bersama dengan alat pembuktian yang diperoleh dari pemeriksaan semasa perbicaraan yang menjadi asas untuk menentukan kesalahan Terdakwa", hal ini dapat di lihat, antara lain :

a. Bahwa panel hakim telah membuat kesimpulan bahawa Terdakwa Mindo Tampubolon, S.IK bukanlah pelaku utama pembunuhan yang direncanakan berdasarkan keterangan de auditu. bahwa Pendakwa Raya telah mengemukakan bukti undang-undang dan memenuhi persyaratan pembuktian, yaitu keterangan 2 (dua) orang saksi, yaitu Gugun Gunawan alias Gugun bin Ade dan saksi Rosita

\footnotetext{
${ }^{20}$ Khambali, M. (2017). Revitalisasi Tata Kelola Peradilan Pidana Berbasis Keadilan Bermartabat. Prosiding Seminar Nasional Multidisiplin Ilmu, 151-160.

21 Rawls, J. (2011). Teori Keadilan Dasar-Dasar Filsafat Politik Untuk Mewujudkan Kesejahteraan Sosial Dalam Negara (Cetakan II). Pustaka Pelajar.

${ }^{22}$ Nasution, B. J. (2014). Kajian Filosofis tentang Konsep Keadilan dari Pemikiran Klasik sampai Pemikiran Modern. Yustisia Jurnal Hukum, 3(2), 118-130.
} 
alias Ros alias Alit binti Pian, keterangan ahli yaitu dr. Adang Azhar, SPF,DFM dan ahli Roy Tenno Siburian, SSi dan petunjuk yang didapatkan di persidangan. Akan tetapi alat bukti tersebut Hakim dikesampingkan dengan bergantung pada keyakinan penyaksian seorang saksi, iaitu saksi Tumpal Manik yang merupakan saksi de auditu yang keterangannya telah ditolak dengan tegas oleh saksi Gugun Gunawan alias Gugun bin Ade dan saksi Rosita alias Ros alias Alit binti Pian yang diberikan di persidangan di bawah sumpah. Bahwa berdasarkan penjelasan Pasal 185 Ayat (1) "dalam pernyataan saksi tidak termasuk maklumat yang diperoleh dari orang lain atau testominium de auditu ". Bahawa keterangan saksi de auditu tidak dapat digunakan sebagai bukti penuh, bahkan dalam banyak keputusan pengadilan, keterangan saksi de auditu dianggap tidak bernilai sebagai bukti.

Pengadilan Negeri Batam dalam putusannya Nomor : 35/Pid.B/2012/PN.BTM (Judex Facti) Adalah salah untuk menerapkan undang-undang pembuktian, yaitu, dalam menafsirkan unsur pelanggaran "dengan sengaja dan dirancang sebelumnya untuk menghilangkan nyawa orang lain", tidak boleh dianggap sepenuhnya dan utuh. Pertimbangan sedemikian bertentangan dengan sistem pembuktian yang diadopsi oleh Kanun Prosedur Jenayah yang mengharuskan bahawa dalam mempertimbangkan unsurunsur kejahatan, unsur-unsur yang dianggap subyektif dan unsur-unsur yang objektif.

a. Bahwa dalam pembuktian unsur "sengaja dan direncanakan terlebih dahulu menghilangkan nyawa orang lain", dalam pertimbangan Majelis Hakim menyebutkan bahwa pengakuan saksi Ujang tersebut oleh saksi Tumpal Manik telah direkam dalam video kamera yang telah disoftcopy dalam flashdisk sehingga rekaman video tersebut merupakan bagian yang tidak terpisahkan dengan keterangan saksi Ujang (alinea ke 5 halaman 75), namun dalam pertimbangan mengenai barang bukti (halaman $87 \mathrm{~s} / \mathrm{d}$ 94) maupun penetapan barang bukti dalam mengadili (halaman $95 \mathrm{~s} / \mathrm{d}$ 103), video kamera yang telah disoftcopy dalam flashdisk tersebut tidak disebutkan sama sekali.

b. Majelis Hakim tidak menerapkan hukum pembuktian tidak berdasakan keterangan ahli :

1. Bahwa Majelis Hakim dalam pertimbangan putusannya pada halaman 84, Majelis telah percaya bahawa berapa lama saksi Ujang berada di hutan tasik punggur kerana mengambil tindakan memotong leher mangsa Puteri Mega Umboh yang telah meninggal dunia. Yang dimiliki oleh Panel Hakim membuat kesimpulan analisa tentang fakta pelaku yang melakukan penggorokan korban Putri Mega Umboh adalah saksi Gugun Gunawan alias Ujang bin Ade tidak berdasarkan keterangan saksi maupun keterangan ahli.

2. Bahwa Ahli Dr. Adang Azhar, Sp.F, DFM menerangkan :

a) Bahwa benar sebab kematian pada korban adalah akibat kekerasan tajam pada leher yang mengakibatkan terputusnya batang tenggorok, kerongkongan, pembuluh nadi dan pembuluh balik utama leher sehingga menimbulkan pendarahan, melihat sifat dan pola luka pada leher sesuai dengan kasus gorok, kekerasan tajam pada perut tidak menyebabkan kematian. 
b) Bahwa benar kekerasan yang ditemukan bagian kepala, leher, lengan kiri dan perut korban Putri Mega Umboh tersebut didapati pada saat masih hidup. Berdasarkan keterangan saksi Gugun Gunawan alias Ujang bin Ade dan saksi Rosita alias Ros alias Alit binti Pian yang memotong leher mangsa Puteri Mega Umboh adalah Terdakwa Mindo Tampubolon, S.Ik.

Dengan demikian cara Hakim dalam menerapkan hukum pembuktian telah salah dan keliru sehingga memutuskan perkara ini juga keliru.

c. Bahwa majelis hakim tidak mempertimbangkan pernyataan saksi secara keseluruhan dan lengkap, yang dikemukakan di bawah bersumpah sebelum perbicaraan sebagai bukti undang-undang berdasarkan Pasal 185 (1) KUHAP, yang terdiri dari :

1. Keterangan saksi Gugun Gunawan alias Ujang bin Ade :

a) Bahwa benar saksi selain dijanjikan uang sebesar Rp25.000.000,00 (dua puluh lima juta rupiah) saksi juga dijanjikan oleh Terdakwa jika nanti seandainya saksi tertangkap oleh Polisi akan dijamin oleh Terdakwa satu minggu dilepaskan.

b) Bahwa benar rencana Kezia akan saksi serahkan kepada Terdakwa sekaligus mengambil uang yang dijanjikan sebesar Rp25.000.000,00 (dua puluh lima juta rupiah).

c) Bahwa benar saksi dan saksi Rosita membeli tiket kapal hanya 2 (dua) orang saja, sementara anak korban Kezia ada bersama saksi karena setelah melakukan pembunuhan tersebut Terdakwa sudah berpesan kepada saksi untuk membawa anaknya sebagai jaminan uang tersebut dan saksi dijanjikan penyerahan uang sebesar Rp25.000.000,00 (dua puluh lima juta rupiah) tersebut pada hari Rabu, tanggal 29 Juni 2011.

2. Keterangan saksi Rosita alias Ros alias Alit binti Pian :

a) Bahwa saksi Gugun Gunawan alias Ujang bin Ade pernah datang ke rumah majikan saksi untuk mengantarkan makanan dan ketika saksi bukakan pintu, tiba-tiba datang majikan laki-laki saksi yaitu Terdakwa dan marah-marah kepada saksi Gugun Gunawan alias Ujang bin Ade sambil menarik kerah baju saksi Gugun Gunawan alias Ujang bin Ade mengatakan "mau apa kau ke sini", Ujang menjawab "mau mengantar nasi untuk Ros" lalu Terdakwa menyuruh saksi Gugun Gunawan alias Ujang bin Ade masuk dan menyuruh saksi naik ke lantai dua sambil mengatakan "kalau ibu (Putri Mega Umboh) nanya bilang aja tamu bapak tapi jangan bilangin tamunya Ujang", kemudian saksi naik ke lantai dua.

b) Bahwa benar terhadap perhiasan emas yang ada pada saksi karena diberikan oleh Terdakwa pada saat akan membuang mayat korban dan perhiasan emas tersebut tidak saksi jual, hanya disimpan saja 
dalam tas dan tidak pernah disuruh oleh Gugun Gunawan alias Ujang bin Ade menjual emas tersebut dan saksi tidak pernah berniat menjualnya.

c) Bahwa benar saksi tidak dendam sama korban.

3. Keterangan Ahli dr. Adang Azhar, SPF, DFM ; (ahli Otopsi / bedah mayat) :

a) Bahwa benar sebab kematian pada korban adalah kerana kekerasan tajam di leher yang mengakibatkan patah batang tenggorok, kerongkongan, pembuluh nadi dan pembuluh balik utama leher sehingga menimbulkan pendarahan. Melihat sifat dan pola luka leher sesuai dengan kasus gorok. Kekerasan tajam pada perut tidak menyebabkan kematian.

b) Bahwa benar dalam kasus ini ahli berpendapat dan yakin korban dibunuh dalam keadaan berdiri.

c) Bahwa benar posisi pelaku berada di belakang korban pada saat penggorokan.

d) Bahwa benar pelaku penggorokan tidak mungkin lebih rendah dari korban.

4. Keterangan Ahli Roy Tenno Siburian, S.Si ; (Ahli Pola darah) :

a) Bahwa ahli jelaskan pada Tempat Kejadian Perkara (TKP) tersebut adalah benar korban telah mengalami luka di bagian tubuh yang mengeluarkan darah begitu banyak.

b) Bahwa benar di sisi lemari, sebelum tindakan pembersihan dilakukan, terdapat lumuran darah yang meluas di sisi kiri lemari tersebut, artinya awal mulanya di sisi kiri lemari sliding door berwarna coklat yang berada di ruang antara kamar mandi dan kamar utama di lantai 2 Perumahan Anggrek Mas 3 Kecamatan Batam Kota terdapat lumuran darah yang banyak sehingga dilakukan pembersihan dengan cara mengelap.

c) Bahwa secara keseluruhan fakta ada 7 (tujuh) tusukan, ada luka gorokan yang memutuskan kerongkongan, ada pola darah percikan (spatter) yang dihasilkan dari pukulan benda tumpul terhadap sumber darah dan ketatnya ikatan pada baju penyumbat mulut mengakibatkan juga terputusnya rambut. Dari semua fakta tersebut menurut pendapat ahli kemungkinan peristiwa pembunuhan dilakukan lebih dari 1 (satu) orang.

d. Bahwa halaman $50 \mathrm{~s} / \mathrm{d} 51$ dalam putusan tersebut terbatas pada keterangan Ahli dr. Adang Azhar, SPF, DFM, dan pada halaman 51 s/d 52 dalam putusan tersebut terbatas pada keterangan Ahli Roy Tenno Siburian, S.Si. Ahli telah memberikan maklumat di bawah sumpah, akan tetapi di dalam putusan tersebut ada sebahagian 
keterangan Ahli yang tidak tercatat dalam putusan dan tidak juga dipertimbangkan (terlampir surat tuntutan Penuntut Umum), dimana apabila keterangan Ahli tersebut dicatat dan dipertimbangkan, maka kemungkinan putusan tersebut akan berbeda. Bahwa berdasarkan Pasal 197 ayat (1) huruf d KUHAP "pertimbangan yang disusun secara ringkas mengenai fakta dan keadaan beserta alat-pembuktian yang diperoleh dari pemeriksaan di sidang yang menjadi dasar penentuan kesalahan Terdakwa ", dengan demikian Majelis Hakim tidak menerapkan aturan ini, keterangan Ahli yang seharusnya mendukung keterangan dari saksi Gugun Gunawan alias Ujang dan saksi Rosita alias Ros (masing-masing penuntutannya terpisah) di sebabkan sebahagian keterangan tersebut tidak termuat dan tidak dipertimbangkan sehingga ada kesan keterangan saksi Gugun Gunawan alias Ujang dan saksi Rosita alias Ros berdiri sendirisendiri sehingga melemahkan pembuktian unsur pasal yang didakwakan, apakah ini ada faktor kesengajaan atau karena ada faktor kelalaian, kami Penuntut Umum menyerahkan seluruhnya kepada Hakim Agung untuk menilai perkara a quo ini. Bahwa dengan tidak dipertimbangkannya seluruh keterangan saksi saksi, keterangan Ahli dan barang bukti yang telah diajukan oleh Penuntut Umum dan Majelis Hakim hanya mengambil keterangan saksi dan Ahli dengan cara partsial saja dan hanya menguntungkan Terdakwa, dengan demikian maksud dari Pasal 197 ayat (1) huruf d KUHAP tidak terpenuhi. Bahwa dengan tidak di penuhinya hal tersebut, maka berdasarkan Pasal 197 ayat (2) KUHAP maka putusan tersebut batal demi hukum.

e. Bahwa pada halaman 79 paragraf 5 dan 6 dan pada halaman 83 paragraf 3 di dalam putusan tersebut, Majelis Hakim Yang Mulia tersebut tidak mempertimbangkan fakta persidangan dari keterangan saksi Gugun Gunawan alias Ujang yang mengatakan di bawah sumpah, pada saat penggorokan tersebut yang dilakukan oleh Terdakwa, saksi Gugun Gunawan alias Ujang langsung melompat karena takut kecipratan darah akibat gorokan tersebut, lagi lagi Majelis Hakim tersebut telah mengambil keterangan keterangan secara parsial saja.

f. Bahwa pada halaman 80 paragraf 2 pada putusan tersebut, Majelis Hakim telah mempertimbangkan keterangan saksi Niko Fernando yang mengatakan saksi tidak pernah sekalipun melihat ada mobil berhenti di rumah Terdakwa, sedangkan fakta nya ialah saksi tidak tahu apakah ada mobil yang berhenti di rumah Terdakwa disebabkan saksi sedang berkerja, bukankan antara frase tidak pernah dan tidak tahu memiliki arti dan makna yang berbeda, lagi lagi terjadi perbedaan catatan sidang antara Penunutut Umum dan Majelis 
Hakim, dan Penuntut Umum menyerahkan kepada Hakim Agung untuk menilai fakta fakta tersebut.

g. Bahwa pada halaman 81 paragraf 1 di dalam putusan tersebut, Majelis Hakim mengatakan bahwa saksi Rosita alias Ros melihat Terdakwa menggorok leher korban dari ruangan TV sehingga terhalang pandangan saksi tersebut, sehingga keterangannya dikesampingkan, lagi-lagi Majelis Hakim tersebut telah mengambil kesimpulan sendiri dan lari dari fakta persidangan, saksi tersebut mengatakan saksi melihat Terdakwa menggorok leher korban, dan posisi saksi pada saat itu ialah di samping TV dan dengan cara mengintip, hal ini sangat singkron dan sangat sesuai pada saat Penuntut Umum memperlihatkan foto rekontruksi yang keterangan saksi sama dengan yang termuat di dalam foto rekontruksi tersebut, dan pada saat dilakukan persidangan setempat, maka apa yang dikatakan saksi yakni mengintip dari samping TV ialah benar adanya yakni bisa dengan jelas melihat peristiwa tersebut, bahwa keterangan saksi ini didukung oleh Ahli yang mengatakan TKPnya berada di dalam rumah di lantai 2 dan luka gorok diperoleh korban semasa hidupnya, dan dengan salahnya Majelis Hakim menafsirkan suatu peristiwa, maka salah juga dalam mengambil keputusan.

h. Bahwa pada halaman 82 paragraf 2, mengatakan saksi Gugun Gunawan alias Ujang memperoleh nomor PIN ATM dari Terdakwa Via Hand Phone, lagi-lagi apa yang tertuang di dalam paragraf tersebut tidak pernah muncul di dalam fakta persidangan, dan timbul pertanyaan darimana suatu peristiwa yang tidak muncul di dalam fakta persidangan turut menjadi pertimbangan di dalam putusan tersebut.

\section{B. Perspektif Hukum Pidana Indonesia Terhadap Pidana Seumur Hidup Atau Pidana Mati Dalam Kasus Tindak Pidana Pembunuhan Berencana}

Hukum pidana merupakan aturan-aturan hukum yang dibuat oleh negara yang berdaulat, yang mana aturan tersebut berisi perbuatan-perbuatan yang dilarang atau diperintahkan dan berisi ancaman pidana, yang memiliki sifat memaksa untuk ditujukan kepada masyarakat (publik), serta penyelenggaraannya dilaksanakan oleh negara melalui alat-alatnya. Perkembangan hukum pidana yang diketahui adalah sebagai alat terakhir (ultimum remedium) dalam memberantas kejahatan-kejahatan di tengah-tengah masyarakat, bahkan dalam kejahatan-kejahatan yang serius dan luar biasa, hukum pidana hadir dan dibutuhkan sebagai upaya terakhir.

Tindak pidana pembunuhan berencana (moord) adalah kejahatan terhadap nyawa manusia yang dilakukan dengan sengaja dan terencana, para pelaku terlebih dahulu dengan tenang memikirkan rencana pembunuhan tersebut sehingga dapat membunuh korban. Delik pembunuhan merupakan delik materiil, harus ada akibat yang dilarang oleh UU lebih dahulu dan dalam hal ini akibat tersebut ialah hilangnya nyawa seseorang. 
Bahwa berangkat dari hal tersebut, ancaman sanksi pidana terhadap delik pembunuhan pun diatur dengan keras dan berat, dimana ancaman pidana nya berupa pidana seumur hidup dan pidana mati. Negara melalui perangkat-perangkatnya melegalitaskan dan mengatur ancaman pidana seumur hidup dan pidana mati tersebut ke dalam sistem pemidanaan Indonesia sebagai hukum positif. Peraturan pidana seumur hidup dapat dilihat pada Pasal 12 KUHP yang berbunyi "Pidana penjara seumur hidup ialah seumur hidup atau selama waktu tertentu" dan jenis-jenis tindak pidana lainnya dalam KUHP yang diancam pidana seumur hidup seperti tindak pidana keamanan negara, tindak pidana terhadap kepala negara dan seterusnya, bahkan sanksi pidana seumur hidup masih dicantumkan di dalam Pasal 68 RUU KUHP 2019. Kemudian di dalam putusan-putusan MA, masih menjatuhkan pidana seumur hidup terhadap para pelaku pembunuhan berencana, seperti putusan Kasasi kasus pembunuhan berencana yang peneliti temukan bahwa pada putusan tingkat pertama melalui nomor putusan: 35/Pid.B/2012/PN.Btm, majelis hakim menyatakan putusan bebas terhadap terdakwa sehingga pada tingkat kasasi, majelis MA melalui nomor putusan: 1691/K/Pid/2012 menjatuhkan putusan pidana seumur hidup terhadap terdakwa, sekaligus menyatakan terdakwa Mindo Tampubolon bersalah menurut hukum.

Putusan kasasi nomor : 1691/K/Pid/2012 terhadap terdakwa Mindo menyatakan bahwa terdakwa terbukti bersalah melakukan pembunuhan yang direncanakan dan menjatuhkan hukuman penjara seumur hidup kepada Terdakwa, putusan kasasi ini sekaligus mematahkan seluruh argument pertimbangan-pertimbangan majelis hakim pada tingkat pertama yang menyatakan unsur-unsur tindak pidana pembunuhan berencana yang di dakwakan terhadap terdakwa tidak terbukti. Jika dikaitkan dengan teori tujuan pemidanaan, yang terdiri dari teori pembalasan, teori tujuan, dan teori gabungan, maka putusan kasasi tersebut harusnya dan patut demi hukum dapat dijatuhi pidana paling maksimal yaitu pidana mati.

Bahwa tujuan pemidanaan tersebut dibagi menjadi 3 (tiga) teori, antara lain sebagai berikut :

a. Teori pembalasan

Teori ini menitikberatkan pemidanaan sebagai bentuk pembalasan untuk memuaskan tuntutan keadilan terhadap korban tindak pidana, karena hakikat dari pidana yaitu pembalasan. Korban maupun pihak korban memiliki akses hukum untuk menuntut keadilan tersebut dan keseimbangan penderitaan yang diterima pihak korban dapat dialami oleh pelaku. Muladi dan Barda Nawawi Arief berpendapat bahawa "jenayah adalah akibat mutlak yang mesti ada sebagai pembalasan terhadap mereka yang melakukan jenayah" Peraturan perundangundangan termasuk KUHP menekankan model retributive justice pada sistem pemidanaaan Indonesia, dengan memberikan sanksi pidana berupa pidana penjara waktu tertentu, pidana seumur hidup, bahkan pidana mati, artinya model retributive justice sebagai teori pemidanaan masih mempunyai power dan eksistensi di dalam hukum pidana positif .

b. Teori tujuan 
Teori ini memiliki konsep penjatuhan pidana terhadap pelaku kejahatan merupakan wujud dalam memberikan perubahan terhadap pelaku kejahatan agar pelaku tidak mengulangi kejahatan yang sama, dan pemidanaan sebagai wujud ancaman sosial bagi masyarakat agar takut sehingga dapat mencegah masyarakat untuk melakukan tindak kejahatan agar ketertiban di dalam masyarakat dapat dipertahankan. Sebagaimana E.Utrech berpandangan "prevensi (pencegahan) umum bertujuan untuk mengelakkan orang secara amnya tidak melanggar, sementara pencegahan khas mempunyai tujuan untuk mengelakkan bahawa pembuat (dader) tidak melanggar" (Rumadan, 2013). Teori relative dalam aspek pemidanaan memiliki 2 tujuan yaitu sebagai pencegahan umum (prevensi general) dan sebagai pencegahan khusus (prevensi special) (Husain, 2014).

c. Teori gabungan

Teori gabungan adalah penggabungan antara teori pembalasan dengan teori tujuan, sehingga unsur pembalasan dapat dilakukan, namun tetap memiliki fungsi pencegahan dan perlindungan terhadap masyarakat. Van Bemmelen sebagai salah satu tokoh teori mengatakan "kejahatan itu bertujuan untuk membalas kesalahan dan mengamankan masyarakat" (Rumadan, 2013). Aspek-aspek perlindungan masyarakat/kepentingan umum (social defence) membawa kesimpulan bahwa tujuan pemidanaan adalah sebagai penanggulangan kejahatan, memperbaiki tingkah laku pelaku kejahatan, sarana untuk membatasi dan mengatur kewenangan penguasa dan warga negara, serta untuk memulihkan keseimbangan di dalam kehidupan masyarakat ${ }^{23}$

Sanksi pidana mati juga masih diatur di dalam sistem pemidanaan nasional, termasuk dalam tindak pidana pembunuhan berencana. Hukum pidana hadir kembali sebagai bentuk hukum yang memiliki ciri khas yang keras dan tajam melalui ancaman pidana nya tersebut. Prof. Achmad Ali menyampaikan bahwa hukuman mati masih dibutuhkan khususnya di Indonesia, namun dalam penerapannya harus spesifik dan selektif (Putusan Mahkamah Konstitusi Republik Indonesia Nomor 2-3/PUU-V/2007, 2007). Spesifik artinya pidana mati dijatuhkan hanya khusus untuk kejahatan-kejahatan serius dan luar biasa (extraordinary chrime) seperti tindak pidana korupsi, narkotika, terorisme, pelanggar HAM berat dan tindak pidana pembunuhan berencana, jadi tidak semua jenis tindak pidana serta merta dapat diancam dengan pidana mati. Selektif, bahwa majelis hakim di pengadilan harus dengan cermat dan yakin dalam menilai alat-alat bukti yang menunjukan memang benar terdakwa adalah pelakunya.

Putusan nomor: 35/Pid.B/2012/PN.Btm adalah salah satu contoh penerapan pidana mati dan pidana seumur hidup yang tidak berjalan dalam kasus tindak pidana pembunuhan berencana secara sadis dan keji, sehingga kemungkinan keadilan menjadi hal yang sulit ditemukan dalam kasus-kasus serupa. Putusan kasasi 1691/K/Pid/2012 terhadap terpidana Mindo Tampubolon harusnya dapat dijatuhi dengan pidana mati sehingga eksistensi pidana mati maupun pidana seumur hidup dalam tindak pidana

${ }^{23}$ Supandriyo. (2019). Asas Kebebasan Hakim Dalam Penjatuhan Pidana Kajian Komprehensif Terhadap Tindak Pidana Dengan Ancaman Minimum Khusus. Arti Bumi Intaran. 
pembunuhan berencana tetap diimplementasikan secara tegas dalam sistem pidana Indonesia, namun dalam kenyataannya belum efektif diterapkan terhadap kasus-kasus tindak pidana pembunuhan berencana.

\section{Penutup}

Pertimbangan hakim atas putusan bebas (vrijspraak) kasus tindak pidana pembunuhan berencana dengan nomor putusan : 35/Pid.B/2012/Pn.Btm yakni, dimana majelis hakim tidak secara cermat dan teliti memperhatikan fakta-fakta persidangan dengan mengamati fakta-fakta keterangan saksi-saksi, ahli dan surat secara menyeluruh sehingga majelis hakim salah menerapkan hukum dalam mempertimbangkan kesalahan terdakwa Mindo. Peneliti berpandangan bahwa putusan tersebut sangat tidak adil, dimana terdakwa Mindo yang merupakan pelaku utama diputus bebas oleh majelis hakim, sedangkan terdakwa Gugun dan terdakwa Ros yang berperan sebagai pembantu dan turut serta sudah diputus bersalah oleh majelis hakim dalam melakukan pembunuhan berencana tersebut. Majelis hakim juga tidak mempertimbangkan kepentingan korban, selain itu putusannya tidak sama sekali bertumpu terhadap urgensinya kasus-kasus kejahatan kemanusiaan di Indonesia yang dilakukan dengan keji dan sadis kepada korban, sehingga akan berdampak pada kerusakan dan terganggunya tatanan ketertiban sosial yang hidup dan berkembang di dalam masyarakat. Putusan MA dengan nomor putusan : $1691 \mathrm{~K} / \mathrm{Pid} / 2012$ membatalkan putusan yang keliru dari putusan judex facti pengadilan negeri Batam nomor : 35/Pid.B/2012/Pn.Btm tersebut, dimana dalam amar putusannya terdakwa dinyatakan terbukti bersalah dalam melakukan pembunuhan berencana secara bersama-sama serta menghukum terdakwa dengan pidana penjara selama seumur hidup. Sesungguhnya 3 (tiga) tujuan dan harapan dari hukum itu sendiri merupakan keadilan, kepastian undangundang dan faedah atau kegunaan, jika kita melihat aspek keadilan, pemenjaraan hukuman mati mesti diimbangi dengan tindakan terdakwa lainnya seperti tindakan pidana narkoba, terorisme, pembunuhan berencana dan yang lainnya..

\section{Daftar Pustaka}

Anindyajati, T., Rachman, I. N., \& Onita, A. A. D. Konstitusionalitas Norma Sanksi Pidana sebagai Ultimum Remedium dalam Pembentukan Perundang-undangan. Jurnal Konstitusi, 12(872-893). 2015

Anjari, W. Penjatuhan Pidana Mati di Indonesia dalam Perspektif Hak Asasi Manusia. Jurnal Widya Yustisia, 1(2), 2015

Anjari, W. Penjatuhan Pidana Mati di Indonesia dalam Perspektif Hak Asasi Manusia. Jurnal Widya Yustisia, 1(2), 2015

Bip, T. R. KUHP Kitab Undang-Undang Hukum Pidana \& KUHAP Kitab UndangUndang Hukum Acara Pidana. Penerbit Bhuana Ilmu Populer,.2017. 
Dwisvimiar, I, Keadilan dalam perspektif filsafat ilmu hukum. Jurnal Dinamika Hukum, 11(3), 2011

Husain, F. U. Implementasi Hukuman Seumur Hidup Dalam Praktik Di Indonesia Menurut KUHP. Lex Et Societatis, 1, 2014.

Julikawati, P. E. Bagir Manan: Hukuman Mati Perlu untuk Beberapa Pidana Berat. Tempo.Co. 2015

Kamea, H. C. Pidana Penjara Seumur Hidup Dalam Sistem Hukum Pidana Di Indonesia. Lex Crimen, 2(2), 2013.

Khambali, M. Revitalisasi Tata Kelola Peradilan Pidana Berbasis Keadilan Bermartabat. Prosiding Seminar Nasional Multidisiplin Ilmu, 2017.

Lumbantoruan, R. (2019). Analisis Yuridis Putusan Bebas terhadap Kasus Tindak Pidana Pembunuhan. Journal of Education, Humaniora and Social Sciences (JEHSS), 2(2), 2019

Marbun, R. Grand Design Politik Hukum Pidana dan Sistem Hukum Pidana Indonesia Berdasarkan Pancasila dan Undang-Undang Dasar Negara Republik Indonesia 1945. Padjadjaran Journal of Law, 1(3), 2014

Nasution, B. J. Kajian Filosofis tentang Konsep Keadilan dari Pemikiran Klasik sampai Pemikiran Modern. Yustisia Jurnal Hukum, 3(2), 2014

Prasetyo, T. Membangun Sistem Hukum Pancasila Yang Merdeka Dari Korupsi dan Menjunjung Ham. Jurnal Refleksi Hukum, 8(1), 2014.

Rahmawati, N. A. Hukum Pidana Indonesia: Ultimum Remedium Atau Primum Remedium. Recidive (Jurnal Hukum Pidana Dan Penanggulangan Kejahatan), 2(1), 2013

Rawls, J. Teori Keadilan Dasar-Dasar Filsafat Politik Untuk Mewujudkan Kesejahteraan Sosial Dalam Negara (Cetakan II). Pustaka Pelajar. 2011

Runtunuwu, G. M. Penjatuhan Pidana Mati Bagi Pelaku Tindak Pidana Narkotika. Lex Crimen, 2(6), 2013.

Simamora, J.. Kepastian Hukum Pengajuan Kasasi Oleh Jaksa Penuntut Umum Terhadap Vonis Bebas Kajian Putusan Mahkamah Konstitusi Nomor 114/Puu-X/2012. Jurnal Yudisial, 7(1), 2014a.

Simbolon, V. E. B., Simarmata, M., \& Rahmayanti. (2019). Tinjauan Yuridis terhadap Tindak Pidana Pembunuhan Berencana Menggunakan Besi Padat di Medan Tinjauan Kasus Nomor 2305/Pid.B/2017/Pn.Mdn. Jurnal Mercatoria, 12(1), 2019.

Supandriyo. Asas Kebebasan Hakim Dalam Penjatuhan Pidana Kajian Komprehensif Terhadap Tindak Pidana Dengan Ancaman Minimum Khusus. Arti Bumi Intaran. 2019

Susilo, A. B. Penegakan Hukum yang Berkeadilan dalam Perspektif Filsafat Hermeneutika Hukum: Suatu Alternatif Solusi terhadap Problematika Penegakan Hukum di Indonesia. Perspektif, 16(4), 2011.

Tresyani, E., D.A., K. N., \& Kusworoningtyas, Y. Pelaksanaan Pembuktian Tindak Pidana Pembunuhan Berencana Di Persidangan Oleh Penuntut Umum Kejaksaan Negeri Surakarta. Verstek Jurnal Hukum Acara, 2(2), 2014

Widayati, L. S. (2017). Pidana Mati Dalam RUU KUHP: Perlukah Diatur Sebagai Pidana 
Volume 15, Nomor 2, Juli-Desember 2020

Yang Bersifat Khusus?(Death Penalty In The Bill Of Criminal Code: Should Regulated As A Special Punishment?). Negara Hukum: Membangun Hukum Untuk Keadilan Dan Kesejahteraan, 7(2), 2017 